\title{
Progression of invasive lionfish in seagrass, mangrove and reef habitats
}

\author{
John Alexander Brightman Claydon*, Marta Caterina Calosso, Sarah Beth Traiger
}

The School for Field Studies Center for Marine Resource Studies, South Caicos, Turks and Caicos Islands

\begin{abstract}
The invasion of the Indo-Pacific lionfish Pterois volitans into the western Atlantic, Caribbean Sea, and Gulf of Mexico is the fastest ever documented for a marine fish. Few studies have addressed the establishment of lionfish populations within a location, and habitats other than reefs have been largely overlooked. The present study reconstructed the invasion around South Caicos, Turks and Caicos Islands (TCI), from multiple sources of data. Densities and size frequencies of lionfish were compared in deep reefs $(10$ to $30 \mathrm{~m})$ and shallow habitats (seagrass, mangrove, sheltered reef, and exposed reef $<5 \mathrm{~m}$ deep) over a 4 yr period (2007 to 2010). By the end of 2010, lionfish had been observed in all 5 habitats. There was a lag of almost 7 mo between the first sightings in shallow habitats (December 2007) and in deep reefs. After 2 to 3 yr, the density of lionfish in deep reefs surpassed those in shallow habitats. In November 2010, mean density was over 10x higher on deep reefs (9.51 lionfish seen observer ${ }^{-1} \mathrm{~h}^{-1} \pm 5.37 \mathrm{SD}$ ) than in seagrass $(0.87 \pm$ $0.41 ; \mathrm{p}<0.05$ ), which was significantly higher than in other shallow habitats (sheltered reef: $0.52 \pm$ 0.47 ; exposed reef: $0.12 \pm 0.13$; and mangrove: $0.06 \pm 0.10 ; \mathrm{p}<0.05)$. Lionfish on deep reefs (TL $=$ $22.7 \pm 7.5 \mathrm{~cm}$ ) had significantly larger total lengths $(\mathrm{TL}$; mean $\pm \mathrm{SD})$ than those in seagrass $(\mathrm{TL}=$ $15.0 \pm 4.3 \mathrm{~cm} ; \mathrm{p}<0.05)$ or sheltered reefs $(\mathrm{TL}=14.6 \pm 6.8 \mathrm{~cm} ; \mathrm{p}<0.05)$. Assuming one population with ontogenetic movement between habitats, density and age estimates suggest that lionfish may have moved to deep reefs from other habitats. The results suggest that lionfish may settle preferentially, but not exclusively, in shallow habitats before moving to deep reefs.
\end{abstract}

KEY WORDS: Pterois volitans - Invasion - Ontogeny $\cdot$ Habitat connectivity $\cdot$ Reef $\cdot$ Seagrass · Mangrove $\cdot$ Turks and Caicos Islands

\section{INTRODUCTION}

The introduction of Indo-Pacific lionfish Pterois miles and P. volitans (Scorpaenidae) into the western Atlantic has led to the fastest invasion documented for marine fish (Morris et al. 2009). Herein collectively referred to as red lionfish, these species have spread throughout the southeast coast of the USA, through the tropical western Atlantic, the Caribbean Sea and the Gulf of Mexico, and are predicted to continue expanding their range south (Schofield 2009, 2010), possibly as far as Uruguay (Morris \& Whitfield 2009), which corresponds to the species' lower thermal limit (Kimball et al. 2004). Whilst both $P$. volitans and $P$. miles have been found on the east coast of the USA, DNA analysis revealed that only $P$. volitans extended its range south through the Bahamas (Freshwater et al. 2009). However, genetic sampling beyond the Bahamas is presently limited.

In their native range, red lionfish are predominantly found on coral, rock, and sand substrata from $<1$ to 50 m (Fishelson 1975, Schultz 1986), although Pterois miles has also been documented in seagrass (Khalaf \& Kochzius 2002). However, perhaps as a reflection of greater research effort and/or being released from the biological controls found in native habitats (i.e. ecological release; Wilson 1961, Lister 1976), in their invasive range lionfish are known to use a wider variety of habitats that include reefs (Albins \& Hixon 2008, Green \& Côté 2009, Schofield 2009), seagrass (Meister et al. 2005, Claydon et al. 2009, Albins \& Hixon in press), and mangroves (Mor- 
ris \& Akins 2009, Barbour et al. 2010), and have been documented at depths from 1 to $>600 \mathrm{~m}$ (Johnston \& Purkis 2011). Whilst reefs are considered to be lionfish's typical habitat (Schofield 2009), and the mean depth of sightings is $35 \mathrm{~m}$ (Johnston \& Purkis 2011), it is currently impossible to determine how well this represents the lionfish's invasive distribution because it is likely to be heavily influenced by biased sampling effort. For example, since most observations are from $<35 \mathrm{~m}$ and appear to have been made by SCUBA divers working at depths within recreational diving limits (Johnston \& Purkis 2011), reefs at depths $<10 \mathrm{~m}$ and $>40 \mathrm{~m}$ and habitats other than reefs are underrepresented.

Only 2 studies have explicitly compared lionfish between different habitats. Barbour et al. (2010) found that mangroves supported higher densities of smaller-sized individuals than nearby reef areas, which has since been interpreted as displaying the nursery function of mangroves (Barbour et al. 2011). Similarly, Biggs \& Olden (2011) reported that lionfish in seagrass were smaller than those found on reefs and suggested that lionfish may use seagrass as nurseries. Although the global concern focuses on lionfish's impact on reefs (Sutherland et al. 2010), evidently the threat also extends to other habitats such as mangroves and seagrass, especially in the context of their nursery function for native species (Nagelkerken 2000, Nagelkerken et al. 2001, Mumby et al. 2004). Therefore, whether ontogenetic changes in habitat use are also displayed by $P$. volitans warrants further investigation (Barbour et al. 2010).

Additionally, whilst the international effort to document the spread of lionfish throughout its invasive range has been considerable (Schofield 2009, 2010, Johnston \& Purkis 2011), far less emphasis has been placed on how a population develops within a new location as it becomes colonized. Thus, quantitative assessments of densities and sizes of lionfish across habitats, depths, and time have not been conducted. Nonetheless, piecing data together from the Bahamas reveals a pattern of lionfish arriving in shallow habitats prior to colonizing deeper ones. The first sightings of lionfish were made in New Providence in 2004, and then lionfish spread throughout the Bahamian islands (Schofield 2009). During 2005 and 2006, lionfish began to be found in new locations in the Bahamas, and, where documented, they were first observed in shallow habitats (Snyder \& Burgess 2006, Albins \& Hixon 2008, Smith \& Sullivan Sealey 2008), but were absent from deeper sites (Lesser \& Slattery 2011). In summer 2007, surveys revealed a substantial number of lionfish at 1 to $4 \mathrm{~m}$ as opposed to deeper areas
(Smith \& Sullivan Sealey 2008). However, by summer 2008 the highest densities of lionfish recorded up to that time (both in the species' introduced and native ranges) were observed on Bahamian reefs at depths between 12 and $20 \mathrm{~m}$ (Green \& Côté 2009). In 2009, even greater densities were observed on mesophotic reefs at 30 to $91 \mathrm{~m}$ (Lesser \& Slattery 2011).

Anecdotal data from throughout the species' invasive range also largely, but not universally, support the pattern from the Bahamas. In Cuba, for example, the first lionfish were documented in shallow water, which included habitats of seagrass and reef at 3 and $9 \mathrm{~m}$, respectively (Chevalier et al. 2008). In Bermuda, the first lionfish recorded was a juvenile captured from a tide pool $<1 \mathrm{~m}$ deep (Whitfield et al. 2002). The first lionfish in Honduras was from a reef at $7 \mathrm{~m}$ (Schofield 2009). The first specimen from the Republic of Colombia came from a patch reef $5 \mathrm{~m}$ deep (Schofield 2009). In the Dominican Republic the first lionfish was from $8 \mathrm{~m}$ (Guerrero \& Franco 2008). In Haiti the first sighting was near a jetty at 2 to $3 \mathrm{~m}$ (Schofield 2009). On the western side of St. Croix, U.S. Virgin Islands, the first lionfish was captured from a pier with a maximum depth of $6 \mathrm{~m}$ (Schofield 2009). Conversely, the first sightings in the southern Gulf of Mexico (Aguilar-Perera \& Tuz-Sulub 2010) and Key Largo, Florida Keys (Schofield 2010), were from reefs at 38 and $20 \mathrm{~m}$ respectively. However, in most locations, these first sightings appear to be opportunistic (see Schofield 2009, 2010) and, therefore, where they are documented may be heavily influenced by the disparity of effort between habitats and depths. Similarly, collating research and opportunistic observations from the Bahamas may also lead to unreliable conclusions because disparity in effort cannot be factored out.

The present study aims to reconstruct the invasion around South Caicos, a small island in the Turks and Caicos Islands (TCI), by accounting for effort to better understand the invasive ecology of this species within multiple habitats. The study compares the densities and size frequencies of lionfish within seagrass, mangrove, and reef habitats and investigates how this changed over the first $4 \mathrm{yr}$ of the invasion (2007 to 2010).

\section{MATERIALS AND METHODS}

\section{Study area}

The TCI are a group of small islands on 2 shallow banks to the southeast of the Bahamas. All data were 


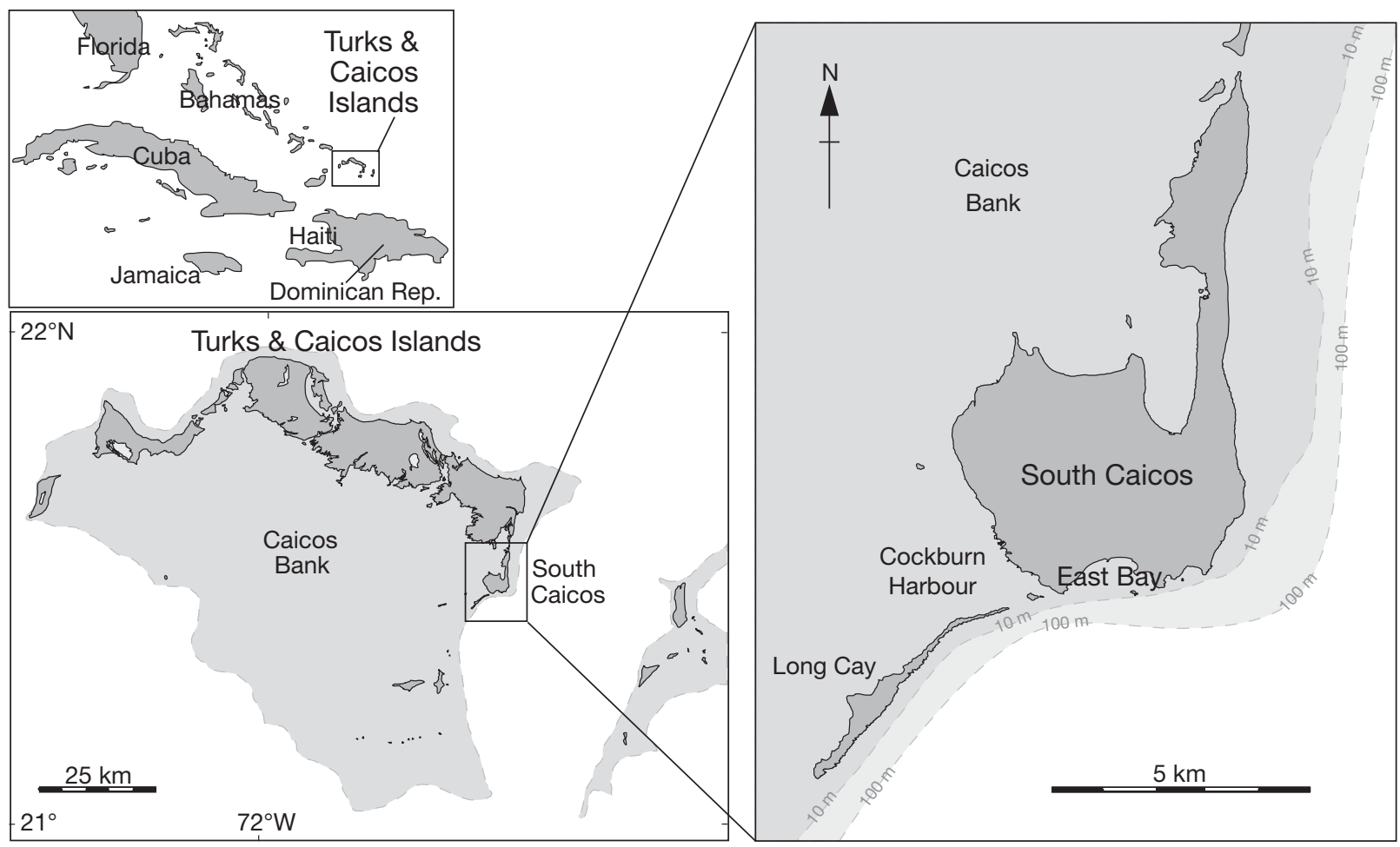

Fig. 1. Study area. Turks and Caicos Islands (TCI), South Caicos and Long Cay

collected from areas around South Caicos and Long Cay on the eastern edge of the Caicos Bank (Fig. 1). During the present study, lionfish removal programs were focused on the more populated islands in the TCI, not South Caicos. Other than collection of specimens for this study, effort to remove lionfish in the study area was negligible and thus unlikely to have influenced the results. All data were collected by staff and students from the Center for Marine Resource Studies (CMRS) on South Caicos.

\section{Habitats}

For the purposes of this study, 5 different marine habitat types were distinguished: mangrove, seagrass, sheltered shallow reef, exposed shallow reef, and deep reef (displayed in Fig. 2). Mangrove habitats were those characterised by submerged roots of predominantly Rhizophora mangle. Only areas where roots were inundated at all states of the tide were sampled. The subtidal mangrove habitat included rocks, corals (especially the finger coral,
Porites porites), sponges, ascidians, and peat ledges. Habitat was classified as mangrove if it was directly under the mangrove canopy or within $1 \mathrm{~m}$ of a mangrove root. The most extensive mangrove habitat in the study area was found lining the shoreline of South Caicos to the west and at the northwest end of the island. However, there was also a small area on the far eastern edge of East Bay (Fig. 2). Whilst mangroves line 
$\sim 10 \mathrm{~km}$ of this coastline the habitat is rarely $>3 \mathrm{~m}$ wide.

Seagrass areas investigated were primarily mixed assemblages of Thalassia testudinum and Syringodium filiforme, but also with limited Halodule beaudettei. These areas frequently had other structures within them, such as corals, rocks, blowouts (eroded areas characterised by a ledge formed by exposed seagrass roots and rhizomes), and patches of sand or rubble. If a contiguous structure within a seagrass bed was $>3 \mathrm{~m}$ in diameter, then it was considered to be an alternative habitat. Seagrass was found in Cockburn Harbour, East Bay, the south end of Long Cay, and the east coast of South Caicos in shallow areas $(<1$ to $5 \mathrm{~m})$ sheltered from the north easterly wind and waves by reefs or landmasses.

Sheltered shallow reefs ( $<1$ to $5 \mathrm{~m}$ deep) were areas of consistently low wave energy protected by windward landmasses or other reefs. These reefs were found in Cockburn Harbour, at the south end of Long Cay, along the entire east coast of South Caicos, around the south west corner of South Caicos and 2 small areas within East Bay. Exposed shallow reefs $(<1$ to $5 \mathrm{~m}$ ) were areas of reef subject to high wave energy and breaking waves. These reefs extended along the eastern coast of South Caicos and Long Cay. Deep reefs (10 to $30 \mathrm{~m}$ ) were found in a band along the eastern edge of the Caicos Bank. All reefs had mixed coverage of coral (both live and dead) and other benthic invertebrates, algae, and rock.

\section{Density}

The relative density of lionfish was calculated within habitat types for each year from 2007 to 2010 . Relative density was measured as the number of individuals seen per observer and per $h$, hereafter referred to as sightings per unit effort (SPUE). Data used in SPUE calculations came from 2 sources:

\section{Center for Marine Resource Studies (CMRS) activities}

In 2007 and 2008, all opportunistic sightings of lionfish made by staff and students at CMRS were recorded. Effort (i.e. hours of observation) within all 5 habitats was estimated from CMRS program activities (education, research, and recreation) conducted on snorkel and SCUBA. Only activities that allowed observers to move around within a habitat were included in the estimate of total effort. In 2009, this protocol was continued for mangrove and exposed shallow reef habitats only.

\section{Surveys}

Surveys were conducted as timed swims, recording the number of lionfish seen, the time spent searching, and the number of observers. In 2008, surveys were performed in mangrove and deep reef habitats from April to June. In February 2009, deep reef habitat was surveyed, and all 5 habitat types were surveyed in November 2009 and in April and November 2010. SCUBA was used for surveys on deep reefs at depths between 12 and $24 \mathrm{~m}$. Surveys in shallow habitats were on snorkel.

Especially during the initial stages of the invasion when lionfish were at very low densities or yet to be detected in some habitats, it was necessary to maximise the effort with which mean yearly SPUE estimates were calculated and thus sources of data were combined where possible (Table 1).

\section{Size}

In order to establish the size frequency distribution of lionfish from different habitats, individuals were captured using hand nets whilst snorkelling or on SCUBA. The depth, habitat, type of shelter being

Table 1. Pterois volitans. Effort (hours of observation) in habitats studied from 2007-2010. CMRS = Center for Marine Resource Studies. Observations in deep reef habitats used SCUBA. -: no data

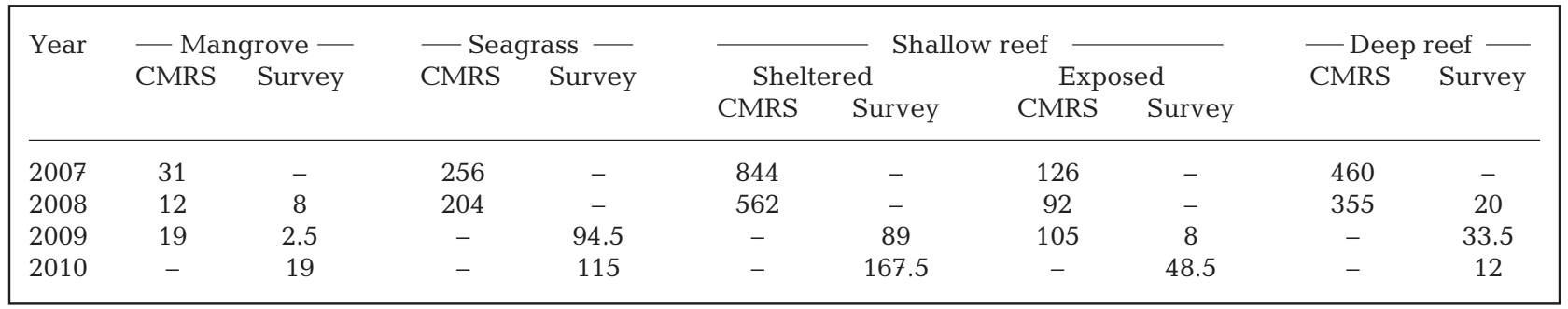


used, and total length (TL, to the nearest $\mathrm{mm}$ ) were recorded for each lionfish caught. In total 267 specimens were captured $(1,14,54$, and 198 lionfish in 2007, 2008, 2009, and 2010, respectively).

\section{Age and settlement}

Ages of all individuals captured were estimated from size (TL) using the von Bertalanffy growth function (VBGF) equation (von Bertalanffy 1938):

$$
T L(t)=L_{\infty}-\left(L \infty-L_{0}\right) \mathrm{e}^{-k t}
$$

Parameter estimates from Barbour et al. (2011) of $L \infty$ (asymptotic length, $42.52 \mathrm{~cm}$ ) and $k$ (growth constant, 0.47 ) were used, and $L_{0}$ was set at $1.2 \mathrm{~cm}$ to represent the estimated size of Pterois volitans at settlement (Fishelson 1975, Hare \& Whitfield 2003; and consistent with recently settled individuals analysed in Ahrenholz \& Morris 2010). In order to estimate the initial dates of invasion around South Caicos, the settlement date of each lionfish was back-calculated from age and date of capture.

\section{Analyses}

A 1-way analysis of variance (ANOVA) with a Tukey's honest significant difference test was used to compare the size of individuals found in seagrass, shallow sheltered reef, and deep reef habitats in November 2010. Mangroves and exposed shallow reefs were excluded from the analyses because of the small sample size from these habitats. Data were checked for homogeneity of variances and normality.

The relative density of lionfish was compared between habitats from data collected in November 2010. This is the only collection period where SPUE could be compared across all habitats. Due to deviation from normality, the non-parametric KruskalWallis test was used. Post-hoc tests were performed using separate Wilcoxon's tests with $\mathrm{p}$ values adjusted using Holm's Bonferroni procedure (Holm 1979).

Detectability of lionfish per unit time, $d$, may have differed between data collection protocols (i.e. CMRS vs. survey and whether SCUBA vs. snorkel was used) and between habitats. The potential for these biases was minimised by: (1) only including activities in CMRS effort estimates that were comparable to surveys; (2) using extensive duck-diving whilst snorkelling to search in crevices, ledges, and overhangs as is facilitated by SCUBA; and (3) only including observations in habitats where water clarity permitted $>8 \mathrm{~m}$ of visibility. However, in order to account for biases that could not be eliminated, the effect of potential differences in $d$ on patterns of relative density was investigated by: (1) assessing the consistency of patterns of SPUE within habitats over time by manipulating $d$ for CMRS activities vs. surveys; and (2) assessing the robustness of the Kruskal-Wallis and Wilcoxon's post-hoc tests performed on SPUE between habitats from November 2010 by simulating different relative levels of $d$ for SCUBA vs. snorkel, and for mangrove vs. seagrass vs. reef habitats. All statistical analyses and simulations were performed using $\mathrm{R}$ (R Development Core Team 2010).

\section{RESULTS}

\section{Initial sightings}

By the end of 2010, lionfish had been observed in all 5 habitat types. However, the timing of when lionfish began to be observed differed substantially between habitats. The first lionfish sighting around South Caicos was made in shallow sheltered reefs in December 2007, followed by the first sighting in seagrass in April 2008, deep reef in June 2008, mangrove in November 2009, and exposed shallow reef in November 2010 (Fig. 3).

\section{Density}

Following the first sightings, relative densities rose consistently throughout the study period in seagrass, sheltered shallow reef, and deep reef habitats (Fig. 3). Unless $d$ was $>3 \times$ higher during surveys than CMRS activities, this pattern of increase was unaffected by potential bias between data collection protocols. In November 2010, SPUE was significantly different between habitats (Kruskal-Wallis: $\chi^{2}=45.18, \mathrm{df}=4, \mathrm{p}<0.05$ ). SPUE was greatest in deep reef $(9.51 \pm 5.37$ lionfish observer ${ }^{-1} \mathrm{~h}^{-1}$; mean $\pm \mathrm{SD}$ ), followed by seagrass $(0.87 \pm 0.41)$, sheltered shallow reef $(0.52 \pm 0.47)$, exposed shallow reef $(0.12 \pm 0.13)$, and mangrove (0.06 \pm 0.10). Post hoc multiple comparisons revealed significant differences in SPUE between all habitats except between exposed shallow reef and mangrove (Table 2). These results were robust to high levels of simulated bias in sampling: signifi- 


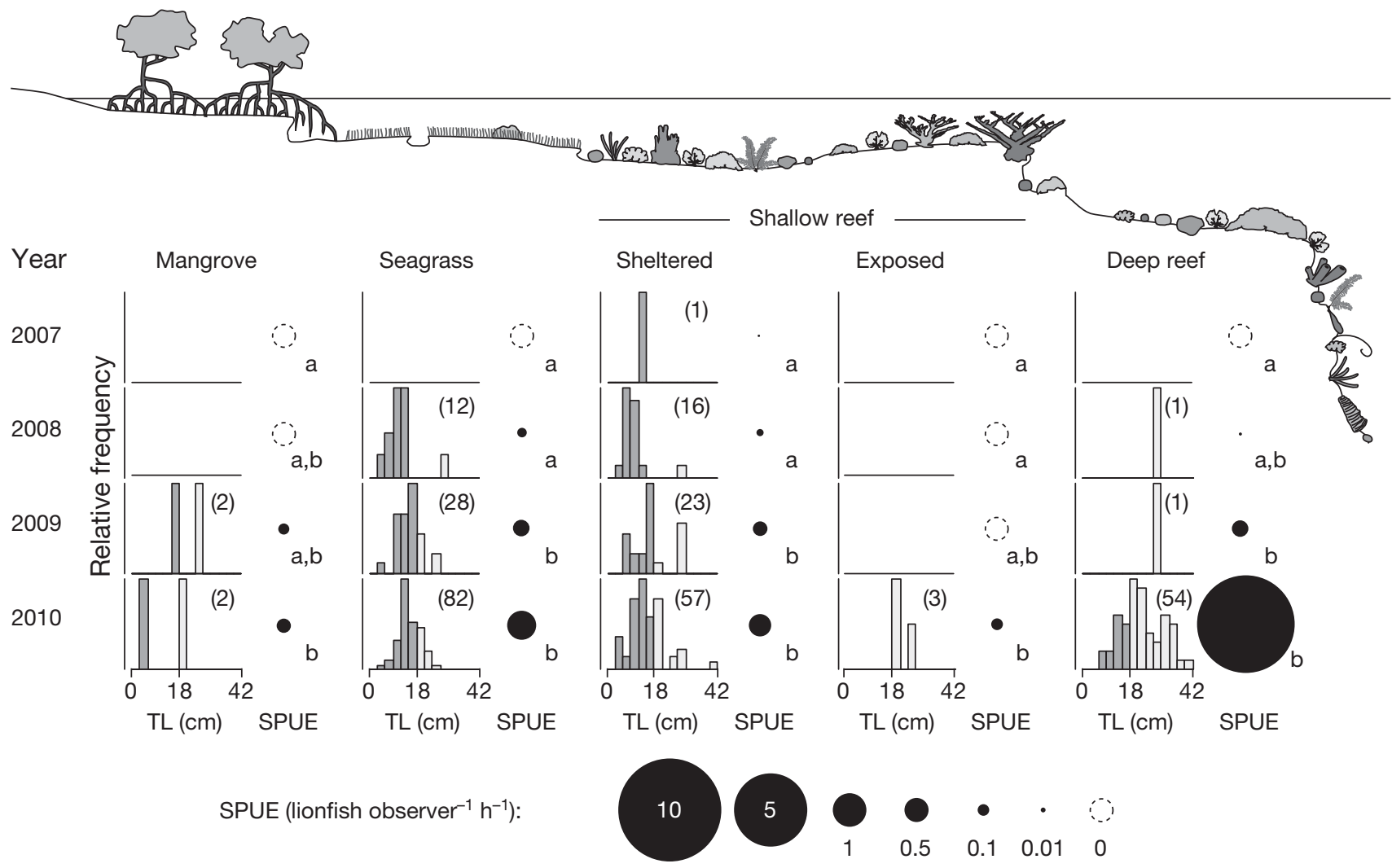

Fig. 3. Pterois volitans. Size frequency distribution of lionfish caught and sightings per unit effort (SPUE) of lionfish in mangrove, seagrass, sheltered shallow reef, exposed shallow reef, and deep reef habitats from 2007 to 2010. Total length (TL) increases in increments of $3 \mathrm{~cm}$. Dark grey bars represent juveniles and light grey bars represent adults following the estimate of $18 \mathrm{~cm}$ TL for size at maturity for females by Morris (2009). Values in parentheses display number of specimens used in distribution. SPUE is proportional to area of dark circles. White circles signify SPUE of zero. Lowercase letters indicate source of data for SPUE: (a) Center for Marine Resource Studies (CMRS) activities, (b) surveys. Data were gathered snorkelling in shallow habitats or using SCUBA on deep reefs (see 'Materials and methods' for details)

Table 2. Pterois volitans. Post-hoc multiple comparisons of sightings per unit effort (SPUE) between different habitats using Wilcoxon's tests (W) with p values adjusted following Holm's Bonferroni procedure. $\mathrm{n}=$ number of surveys in habitat; -: no data; ${ }^{*} \mathrm{p}<0.05 ;$ n.s.: $\mathrm{p}>0.05$

\begin{tabular}{|c|c|c|c|c|c|c|c|c|c|}
\hline & & \multicolumn{2}{|c|}{$\begin{array}{c}\text { Deep reef } \\
(\mathrm{n}=15)\end{array}$} & \multicolumn{2}{|c|}{$\begin{array}{c}\text { Seagrass } \\
(\mathrm{n}=12)\end{array}$} & \multicolumn{2}{|c|}{$\begin{array}{c}\text { Sheltered } \\
\text { reef }(\mathrm{n}=23)\end{array}$} & \multicolumn{2}{|c|}{$\begin{array}{l}\text { Exposed } \\
\text { reef }(n=7)\end{array}$} \\
\hline & & W & $\mathrm{p}$ & $\mathrm{W}$ & $\mathrm{p}$ & $\mathrm{W}$ & $\mathrm{p}$ & W & $\mathrm{p}$ \\
\hline Seagrass & $(\mathrm{n}=12)$ & 170 & $*$ & - & - & - & - & - & - \\
\hline Sheltered reef & $(\mathrm{n}=23)$ & 274 & ${ }^{*}$ & 81 & ${ }^{*}$ & - & - & - & - \\
\hline Exposed reef & $(\mathrm{n}=7)$ & 84 & * & 102 & * & 144 & * & - & - \\
\hline Mangrove & $(\mathrm{n}=6)$ & 72 & $*$ & 88 & * & 131 & * & 13 & n.s. \\
\hline
\end{tabular}

Size

There was a significant difference in the sizes of lionfish caught in seagrass, sheltered shallow reef, and deep reef habitats (1-way ANOVA: $\left.F_{3,270}=37.45, \mathrm{p}<0.05\right)$. Tukey's HSD tests revealed that lionfish in deep reef were significantly larger $(22.7 \pm$ $7.5 \mathrm{~cm}$ TL, mean \pm SD) than seagrass $(15.0 \pm 4.3 ; \mathrm{p}<0.05)$ and sheltered reef $(14.6 \pm 6.8 ; \mathrm{p}<0.05)$, but there was no significant difference be-

cance was lost only if SPUE was underestimated by factors of $\geq 6.58$ using snorkel compared to SCUBA, $\geq 6.58$ sampling in seagrass compared to reef, $\geq 1.56$ sampling in reef compared to seagrass, $\geq 2.90$ sampling in mangrove compared to reefs, or $\geq 5.62$ sampling in mangrove compared to seagrass. tween the sizes of individuals caught in shallow habitats $(\mathrm{p}>0.05)$. Hand nets were more effective at capturing smaller individuals. As such, >95\% of lionfish approached in shallow habitats were captured whereas a number of larger individuals evaded capture on deep reefs. 


\section{Age and settlement}

Estimation of age from sizes using the von Bertalanffy growth function revealed that most individuals caught in shallow habitats were from Year 0 (71\%) and Year $1(25 \%)$, with $<5 \%$ from Year 2 or older (Fig. 4). Conversely, lionfish caught in deep reef habitats were less represented in Year 0 (21\%), and more represented in Year 1 (45\%) and Year 2 and above $(34 \%)$. Back-calculation of settlement dates
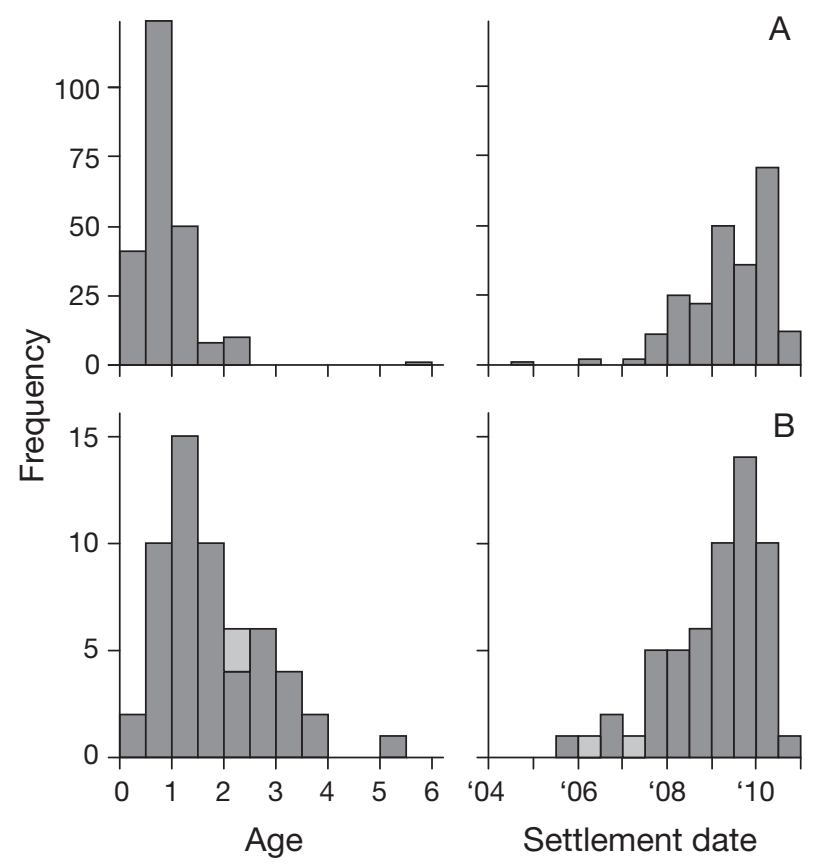

Fig. 4. Pterois volitans. Frequency of age classes and corresponding settlement dates from specimens captured on (A) combined shallow habitats $(\mathrm{n}=234)$ and $(\mathrm{B})$ deep reefs $(\mathrm{n}=$ 56). Ages were estimated from sizes using the von Bertalanffy growth function with $L^{\infty}=42.52$ and $k=0.47$ from Barbour et al. (2011) and $L_{0}$ set to $1.2 \mathrm{~cm}$. Individuals from shallow habitats were captured from 2007 to 2010. Dark grey bars in (B) represent specimens captured in 2010 and light grey represents individuals caught in 2008 and 2009 indicated that lionfish first settled around South Caicos at least as early as 2004 (Fig. 4).

\section{Shelter use}

Most lionfish were observed sheltering in association with (i.e. on, under, in, or around) biotic and abiotic structures, including rocks, coral heads (live or dead), rubble, and man-made structures (including concrete block, seawalls, posts, fish traps wreckage and trash) as well as softer structures such as sponges, the walls of blowouts in seagrass areas and undercut peat banks in mangrove root systems (Table 3).

\section{DISCUSSION}

Although lionfish were first observed in shallow habitats in December 2007, back-calculation of settlement dates from individuals' sizes indicated that lionfish may have started settling in the study area from as early as 2004, but at densities too low to be detected at the time. Since 2007, the density of Pterois volitans has increased around South Caicos, but the timing and rate of increase differed substantially between habitats and did not appear to reflect simple habitat preference: in 2008, SPUE of lionfish in seagrass was $20 \times$ higher than on deep reefs. But in 2009, relative densities were similar across seagrass, shallow sheltered reef, and deep reef habitats, and, although densities continued to rise in seagrass and sheltered reefs, by the end of 2010, SPUE on deep reefs was over an order of magnitude higher than in any other habitat.

Lionfish caught on deep reefs were significantly larger than those found in shallow habitats. The difference in mean size $(>7 \mathrm{~cm})$ is likely to be underestimated because a number of large individuals on

Table 3. Pterois volitans. Shelter use by lionfish in different habitats. $\mathrm{n}=$ number of individuals observed; - : no data

\begin{tabular}{|c|c|c|c|c|c|c|c|c|c|c|}
\hline \multirow[t]{2}{*}{ Habitat } & & \multirow[t]{2}{*}{$\mathrm{n}$} & \multicolumn{8}{|c|}{ Shelter $(\%)$} \\
\hline & & & $\begin{array}{l}\text { Peat } \\
\text { bank }\end{array}$ & $\begin{array}{c}\text { Blowout } \\
\text { wall }\end{array}$ & $\begin{array}{l}\text { Rock/ } \\
\text { coral }\end{array}$ & Rubble & Sand & Sponge & $\begin{array}{l}\text { Man- } \\
\text { made }\end{array}$ & Other \\
\hline \multicolumn{2}{|l|}{ Mangrove } & 5 & 80 & - & - & 20 & - & - & - & - \\
\hline \multirow[t]{2}{*}{ Seagrass } & Blowout & 132 & - & 83 & 8 & 2 & 1 & - & 6 & - \\
\hline & Non-blowout & 4 & - & - & 50 & - & - & - & 50 & - \\
\hline \multirow[t]{3}{*}{ Reef } & Sheltered & 119 & - & - & 80 & 7 & - & - & 12 & 1 \\
\hline & Exposed & 5 & - & - & 100 & - & - & - & - & - \\
\hline & Deep & 165 & - & - & 94 & 1 & 3 & 2 & - & - \\
\hline
\end{tabular}


deep reefs evaded capture with hand nets. Backcalculation of settlement dates of individuals caught on deep reefs in 2010 indicated that $35 \%$ settled before 2009, yet only 1 individual was seen during this time period on deep reefs. Almost $80 \%$ settled before 2010, but the SPUE in 2009 was over $40 \times$ lower than in 2010. The growth parameter $k$ used in the VBGF upon which these estimates were based came from specimens caught in North Carolina, USA (Barbour et al. 2011). Pterois volitans may grow more quickly in the warmer waters of the TCI, but even if $k$ is doubled, this discrepancy remains, with $37 \%$ predicted to have settled before 2010 , and $17 \%$ if $k$ is trebled (which would correspond to attaining TLs of 26 and $32 \mathrm{~cm}$, respectively, within $1 \mathrm{yr}$ ).

It is possible that lionfish are less detectable at smaller size classes within deep reef rather than shallow habitats, but many individuals would have been large by 2008 and 2009 and thus should have been reflected in higher SPUE values. A hypothesis that fits all of the observations in the present study is that lionfish preferentially (but not exclusively) settle in shallow habitats, especially seagrass and sheltered reefs, but also mangroves, before moving to deep reefs once they have grown larger. Such changes in habitats with ontogeny are well known for a number of fishes that inhabit reefs as adults (Eggleston 1995, Green 1996, Frias-Torres 2006, Wilson et al. 2010) and was suggested by Barbour et al. (2011) to explain why lionfish at a site in the Bahamas were found at smaller sizes in mangroves compared to nearby reefs and by Biggs \& Olden (2011) to explain a similar size difference between specimens in seagrass and reefs in Honduras. This hypothesis is also supported anecdotally by the pattern of lionfish establishment collated from reports in the Bahamas and by the majority of first sightings of lionfish in new locations being made in shallow habitats (see 'Introduction').

The extensive use of back-reef habitats similar to those investigated in this study (i.e. mangroves, seagrass, and sheltered shallow reefs) by fishes and invertebrates at early stages before moving to deeper reef areas when larger (Nagelkerken 2000, Adams et al. 2006) has been proposed to increase growth rates through greater access to food (Beck et al. 2001). However, empirical studies largely refute this (Dahlgren \& Eggleston 2000, Sheridan \& Hays 2003, Grol et al. 2008, 2011). There is more support for the hypothesis that smaller size classes are afforded greater refuge from predators in shallow habitats (see reviews in Heck et al. 2003, Sheridan \& Hays 2003) and that choice of these habitats reflects a trade-off between growth and survival, favouring survival at the expense of reduced growth (Dahlgren \& Eggleston 2000, Grol et al. 2008, 2011). For venomous species such as Pterois miles and P. volitans that have few known predators (Bernadsky \& Goulet 1991), it is not obvious that such a trade-off still exists and habitat choice should perhaps be driven by simply maximizing growth and thus avoiding shallow habitats. However, levels of predation during and shortly after settlement have not been investigated, and the low densities of lionfish in their native ranges (Fishelson 1997, Grubich et al. 2009) might be explained by predation at these early stages. In addition adult $P$. volitans have been observed preying on conspecific juveniles in captivity (Fishelson 1997), and thus settling in habitats with fewer adults may also limit cannibalistic mortality.

In the study area, lionfish would need to move hundreds of meter to $>1 \mathrm{~km}$ from shallow habitats to reach deep reefs. Although lionfish are generally considered to be sedentary and site-attached as both juveniles and adults (Fishelson 1975, 1997, Kochzius \& Blohm 2005), other observations support the ability of Pterois volitans to move more extensively: in the Red Sea, $P$. volitans has been described as living in small groups and dispersing as adults (Fishelson 1997), moving between shallow and deeper areas with the tide, and males are reported as searching widely for females prior to spawning (Fishelson 1975). Similarly, a smaller lionfish, Dendrochirus zebra, has been documented hunting over large home ranges and migrating to spawn (Moyer \& Zaiser 1981). Therefore, movement over the distances necessary for $P$. volitans to reach deep reefs from shallow habitats is plausible.

Whilst lionfish were observed in shallow sheltered reefs, they were conspicuously absent from adjacent exposed reef habitats around South Caicos, with none observed until 2010. Although other factors cannot be excluded, lionfish appear to favour less turbulent habitats, and this corresponds with the observation that they are common in harbours (Schultz 1986). However, if lionfish move from shallow to deep habitats, then passing through exposed reef areas would be necessary in many instances around South Caicos. Accordingly, the few individuals observed in exposed reef habitats may represent such individuals in transit between the seagrass and sheltered reef areas within East Bay and the deep reef areas further offshore.

Although lionfish have been documented in seagrass areas in their invasive range (Meister et al. 2005, Claydon et al. 2009, Biggs \& Olden 2011, Albins \& Hixon in press) and in native locations (Pterois 
miles; Khalaf \& Kochzius 2002), research has focused on reef habitats. This is unsurprising because the highest densities of $P$. volitans have been found on deep reefs (Green \& Côté 2009, Lesser \& Slattery 2011), and may be over an order of magnitude higher than in shallow non-reef habitats, as documented in 2010 in the present study. Had data not been collected during the early years of the invasion (i.e. whilst densities on deep reefs were still low), the role of seagrass in the lionfish invasion of South Caicos may also have been obscured.

However, the relative importance of shallow habitats to a number of reef fish species has been shown to be highly location-specific and dependent on local geography (Faunce \& Serafy 2007, 2008). This is also likely to be the case for Pterois volitans, being influenced by the area of habitats available, their proximities to alternative or adult habitats, and their spatial arrangement from the perspective of settling larvae. Extensive use of mangroves has been highlighted around San Salvador, in the Bahamas (Barbour et al. 2010), even suggesting that these areas could serve as lionfish nurseries (Barbour et al. 2011). However, as a combination of the low relative densities documented in the present study and the small area covered by mangroves, their contribution to populations around South Caicos may be limited, with only 5 individuals observed in mangroves since 2007. Similarly, whilst seagrass appears to be the most important shallow habitat for lionfish around South Caicos, with approximately double the density found in sheltered reefs in 2010, in Roatan, Honduras, lionfish were less abundant in seagrass than shallow reefs (Biggs \& Olden 2011).

The present study is the first to document the progression of the Pterois volitans invasion in multiple habitats over time and to demonstrate the importance of seagrass areas to lionfish. Regardless of the adaptive significance of using shallow areas, understanding the habitat use of lionfish in its invasive range is of crucial importance to management efforts, but has received surprisingly little attention. As theoretical studies addressing the efficacy of removal efforts develop (Barbour et al. 2011, Morris et al. 2011), a more complete understanding is invaluable, especially if ontogenetic movements are occurring. Numerous complementary approaches can be used to investigate this, including tagging and analysis of chemical signatures in otoliths. However, the importance of different habitats may vary considerably between and even within different locations, being affected by availability, quality, and connectivity of habitats.
Acknowledgements. We acknowledge The School for Field Studies, Center for Marine Resource Studies, for financial and logistical support, and the Turks and Caicos Islands (TCI) Government Department of Environment and Coastal Resources for supporting the project. We thank 3 anonymous reviewers for constructive comments. Manuscript preparation was facilitated through the Fred Karush Endowed Library Readership at the Marine Biological Laboratory Woods Hole Oceanographic Institution Library. We give special thanks to the Center for Marine Resource Studies staff and students for assistance in the field, especially J. Brown, J. Catlin, L. Habegger, S. Jacob, J. Lupton, W. Maclennan, L. McNamee, M. Steiger, C. Wagner, J. Clauson, C. Cormier, E. Fox, F. Hoogakker, B. Hooper, J. Ju, K. Ketch, C. Lamendola, M. Mansuy, K. Moy, D. Myers, K. McHenry, D. Short, L. Sperry, M. Swenarton, and B. Talwar. We dedicate this manuscript to the memory of A. Paganelli who also assisted in the field.

\section{LITERATURE CITED}

Adams AJ, Dahlgren CP, Kellison T, Kendall MS and others (2006) Nursery function of tropical back-reef systems. Mar Ecol Prog Ser 318:287-301

Aguilar-Perera A, Tuz-Sulub A (2010) Non-native, invasive red lionfish (Pterois volitans [Linnaeus, 1758]: Scorpaenidae), is first recorded in the southern Gulf of Mexico, off the northern Yucatan Peninsula, Mexico. Aquat Invasions 5:S9-S12

Ahrenholz DW, Morris JA Jr. (2010) Larval duration of the lionfish, Pterois volitans along the Bahamian Archipelago. Environ Biol Fishes 88:305-309

Albins MA, Hixon MA (2008) Invasive Indo-Pacific lionfish Pterois volitans reduce recruitment of Atlantic coral-reef fishes. Mar Ecol Prog Ser 367:233-238

Albins MA, Hixon MA (in press) Worst case scenario: potential long-term effects of invasive predatory lionfish (Pterois volitans) on Atlantic and Caribbean coral-reef communities. Environ Biol Fishes

Barbour AB, Montgomery ML, Adamson AA, Díaz-Ferguson E, Silliman BR (2010) Mangrove use by the invasive lionfish Pterois volitans. Mar Ecol Prog Ser 401:291-294

> Barbour AB, Allen MS, Frazer TK, Sherman KD (2011) Evaluating the potential efficacy of invasive lionfish (Pterois volitans) removals. PLoS ONE 6:e19666 doi:10.1371/ journal.pone.0019666

Beck MW, Heck KL, Able KW, Childers DL and others (2001) The identification, conservation, and management of estuarine and marine nurseries for fish and invertebrates. Bioscience 51:633-641

Bernadsky G, Goulet D (1991) A natural predator of the lionfish Pterois miles. Copeia 1991:230-231

Biggs CR, Olden JD (2011) Multi-scale habitat occupancy of invasive lionfish (Pterois volitans) in coral reef environments of Roatan, Honduras. Aquat Invasions 6:347-353

Chevalier PO, Gutierrez E, Ibarzabal D, Romero S, Isla V, Calderin J, Hernendez E (2008) Primer registro de Pterois volitans (Pisces: Scorpaenidae) para aguas cubanas. Solendon 7:37-40

Claydon JAB, Calosso MC, Jacob SE (2009) The red lionfish invasion of South Caicos, Turks \& Caicos Islands. Annu Proc Gulf Caribb Fish Inst 61:400-402

$>$ Dahlgren CP, Eggleston DB (2000) Ecological processes underlying ontogenetic habitat shifts in a coral reef fish. Ecology 81:2227-2240 
Eggleston DB (1995) Recruitment in Nassau grouper Epinephelus striatus: post-settlement abundance, microhabitat features, and ontogenetic habitat shifts. Mar Ecol Prog Ser 124:9-22

Faunce CH, Serafy JE (2007) Nearshore habitat use by gray snapper (Lutjanus griseus) and bluestriped grunt (Haemulon sciurus): environmental gradients and ontogenetic shifts. Bull Mar Sci 80:473-495

Faunce CH, Serafy JE (2008) Selective use of mangrove shorelines by snappers, grunts, and great barracuda. Mar Ecol Prog Ser 356:153-162

Fishelson L (1975) Ethology and reproduction of pteroid fishes found in the Gulf of Aqaba (Red Sea), especially Dendrochirus brachypterus (Cuvier), (Pteroidae, Teleostei). Pubbl Stn Zool Napoli 39:635-656

Fishelson L (1997) Experiments and observations on food consumption, growth and starvation in Dendrochirus brachypterus and Pterois volitans (Pteroinae, Scorpaenidae). Environ Biol Fishes 50:391-403

Freshwater DW, Hines A, Parham S, Wilbur A and others (2009) Mitochondrial control region sequence analyses indicate dispersal from the US east coast as the source of the invasive Indo-Pacific lionfish Pterois volitans in the Bahamas. Mar Biol 156:1213-1221

Frias-Torres S (2006) Habitat use of juvenile goliath grouper Epinephelus itajara in the Florida Keys, USA. Endang Species Res 2:1-6

$>$ Green AL (1996) Spatial, temporal and ontogenetic patterns of habitat use by coral reef fishes (Family Labridae). Mar Ecol Prog Ser 133:1-11

- Green AL, Côté IM (2009) Record densities of Indo-Pacific lionfish on Bahamian coral reefs. Coral Reefs 28:107

> Grol MGG, Dorenbosch M, Kokkelmans EMG, Nagelkerken I (2008) Mangroves and seagrass beds do not enhance growth of early juveniles of a coral reef fish. Mar Ecol Prog Ser 366:137-146

> Grol MGG, Nagelkerken I, Rypel AL, Layman CA (2011) Simple ecological trade-offs give rise to emergent crossecosystem distributions of a coral reef fish. Oecologia 165:79-88

> Grubich JR, Westneat MW, McCord CL (2009) Diversity of lionfishes (Pisces: Scorpaenidae) among remote coral reefs of the Palau Archipelago. Coral Reefs 28:807

Guerrero KA, Franco AL (2008) First record of the IndoPacific red lionfish Pterois volitans (Linnaeus, 1758) for the Dominican Republic. Aquat Invasions 3:267-268

Hare JA, Whitfield PE (2003) An integrated assessment of the introduction of lionfish (Pterois volitans/miles complex) to the western Atlantic Ocean. NOAA Technical Memorandum NOS NCCOS 2:1-21

> Heck KL, Hays G, Orth RJ (2003) Critical evaluation of the nursery role hypothesis for seagrass meadows. Mar Ecol Prog Ser 253:123-136

Holm S (1979) A simple sequentially rejective multiple test procedure. Scand J Stat 6:65-70

> Johnston MW, Purkis SJ (2011) Spatial analysis of the invasion of lionfish in the western Atlantic and Caribbean. Mar Pollut Bull 62:1218-1226

Khalaf MA, Kochzius M (2002) Community structure and biogeography of shore fishes in the Gulf of Aqaba, Red Sea. Helgol Mar Res 55:252-284

Kimball ME, Miller JM, Whitfield PE, Hare JA (2004) Thermal tolerance and potential distribution of invasive lionfish (Pterois volitans/miles complex) on the east coast of the United States. Mar Ecol Prog Ser 283:269-278
Kochzius M, Blohm D (2005) Genetic population structure of the lionfish Pterois miles (Scorpaenidae, Pteroinae) in the Gulf of Aqaba and northern Red Sea. Gene 347:295-301

> Lesser MP, Slattery M (2011) Phase shift to algal dominated communities at mesophotic depths associated with lionfish (Pterois volitans) invasion on a Bahamian coral reef. Biol Invasions 13:1855-1868

- Lister BC (1976) The nature of niche expansion in West Indian Anolis lizards. I. Ecological consequences of reduced competition. Evolution 30:659-676

Meister HS, Wyanski DM, Loefer JK, Ross SW, Quattrini AM, Sulak KJ (2005) Further evidence for the invasion and establishment of Pterois volitans (Teleostei: Scorpaenidae) along the Atlantic coast of the United States. Southeast Nat 4:193-206

Morris JA Jr. (2009) The biology and ecology of the invasive Indo-Pacific lionfish. PhD dissertation, North Carolina State University, Raleigh, North Carolina

Morris JA Jr., Akins JL (2009) Feeding ecology of invasive lionfish (Pterois volitans) in the Bahamian archipelago. Environ Biol Fishes 86:389-398

> Morris JA Jr., Whitfield PE (2009) Biology, ecology, control and management of the invasive Indo-Pacific lionfish: an updated integrated assessment. NOAA Technical Memorandum NOS NCCOS 99:1-57

Morris JA Jr., Akins JL, Barse A, Cerino D and others (2009) Biology and ecology of the invasive lionfishes, Pterois miles and Pterois volitans. Annu Proc Gulf Caribb Fish Inst 61:1-6

> Morris JA Jr., Shertzer KW, Rice JA (2011) A stage-based matrix population model of invasive lionfish with implications for control. Biol Invasions 13:7-12

Moyer JT, Zaiser MJ (1981) Social organization and spawning behavior of the pteroine fish Dendrochirus zebra at Miyake-jima, Japan. Jpn J Ichthyol 28:52-69

> Mumby PJ, Edwards AJ, Arias-González JE, Lindeman KC and others (2004) Mangroves enhance the biomass of coral reef fish communities in the Caribbean. Nature 427:533-536

> Nagelkerken I (2000) Importance of mangroves, seagrass beds and the shallow coral reef as a nursery for important coral reef fishes, using a visual census technique. Estuar Coast Shelf Sci 51:31-44

Nagelkerken I, Kleijnen S, Klop T, van den Brand RACJ, Cocheret de la Morinière E, van der Velde G (2001) Dependence of Caribbean reef fishes on mangroves and seagrass beds as nursery habitats: a comparison of fish faunas between bays with and without mangroves/seagrass beds. Mar Ecol Prog Ser 214:225-235

R Development Core Team (2010). R: a language and environment for statistical computing. R Foundation for Statistical Computing, Vienna, Austria. http://www.Rproject.org accessed July 2010

Schofield PJ (2009) Geographic extent and chronology of the invasion of non-native lionfish (Pterois volitans [Linnaeus 1758] and P. miles [Bennett 1828]) in the western north Atlantic and Caribbean Sea. Aquat Invasions 4: 473-479

Schofield PJ (2010) Update on geographic spread of invasive lionfishes (Pterois volitans [Linnaeus, 1758] and P. miles Bennett, 1828]) in the western north Atlantic Ocean, Caribbean Sea and Gulf of Mexico. Aquat Invasions 5: 117-122

Schultz ET (1986) Pterois volitans and Pterois miles: two valid species. Copeia 1986:686-690 
Sheridan P, Hays C (2003) Are mangroves nursery habitat for transient fishes and decapods. Wetlands 23:449-458 Smith NS, Sullivan Sealey KS (2008) The lionfish invasion in the Bahamas: what do we know and what can we do about it? Annu Proc Gulf Caribb Fish Inst 60:419-423

Snyder DB, Burgess GH (2006) The Indo-Pacific red lionfish, Pterois volitans (Pisces: Scorpaenidae), new to Bahamian ichthyofauna. Coral Reefs 26:175

Sutherland WJ, Clout M, Côté IM, Daszak P and others (2010) A horizon scan of global conservation issues for 2010. Trends Ecol Evol 25:1-7

von Bertalanffy L (1938) A quantitative theory of organic growth (inquiries on growth laws. II.). Hum Biol 10:

Editorial responsibility: Charles Birkeland,

Honolulu, Hawaii, USA
$181-213$

> Whitfield PE, Gardner T, Vives SP, Gilligan MR, Courtenay WR, Ray GC, Hare JA (2002) Biological invasion of the Indo-Pacific lionfish Pterois volitans along the Atlantic coast of North America. Mar Ecol Prog Ser 235: 289-297

Wilson EO (1961) The nature of the taxon cycle in Melanesian ant fauna. Am Nat 95:169-193

Wilson SK, Depczynski M, Fisher R, Holmes TH, O'Leary RA, Tinkler P (2010) Habitat associations of juvenile fish at Ningaloo Reef, Western Australia: the importance of coral and algae. PLoS ONE 5:e15185 doi:10.1371/ journal.pone.0015185

Submitted: June 8, 2011; Accepted: November 29, 2011

Proofs received from author(s): February 11, 2012 